\title{
The role of visibility and career advancement of women in Kenya
}

\author{
Teresia Kavoo Linge, Willie VanRensburg \& Damary Sikalieh
}

\begin{abstract}
The purpose of this study was to investigate whether women employees are visible in their organizations in Kenya. The study was a cross-sectional survey carried out among women employees of the Federation of Kenya Employers (FKE) member organizations. Stratified and random sampling was used to select a sample of 400 women employees. Data were collected using a self administered questionnaire and analysed using both quantitative and qualitative techniques. The results indicate that the visibility of women in their organizations is low.
\end{abstract}

Key words: visibility, women, Kenya, career advancement

\section{Introduction}

One of the concerns of career research has been on the underrepresentation of women in managerial positions. In this connection various researchers have focused on factors which lead to the progression of women managers (Kirchmeyer, 1998, Maxifield, 2005 and Garavan, O'brien and O'Hanlon, 2006). Some of the factors which have been suggested as leading to women's career advancement include mentoring, training and development, career planning, individual characteristics, and hard work (Ismail and Arokiasamy, 2007; Burke, Burgess and Fallon 2006) among others. Ackah and Heaton (2003) define career advancement as comprising of promotions and increased earnings. An employee may get increased earnings in the form of merit pay, bonus pay and cash awards (Dessler, 2008). In Kenya, researchers have mainly focused on the barriers faced by women managers. This research takes the research agenda on women's career advancement further by focusing in particular on the visibility of women in Kenyan organizations.

Visibility involves putting yourself into the limelight or allowing yourself to be positioned there and it involves risk (Driscoll and Goldberg, 1993). Vinnicombe and Singh (2003) state that an individual's visibility may lead to their public approval and success. In an organization, an employee's visibility is important because the evaluation of effective performance can be very subjective, it's important that one's supervisor and those in power in organizations are made aware of one's contribution (Robbins and Coulter, 1999). According to Snape, Redman and Bamber (1994) women may lose out in terms of promotion because senior managers do not know them well or have an inaccurate view of their ambitions and may therefore underrate their job performance. Lemons and Parzinger (2001) indicate that because supervisors were unlikely to attribute the performance of women to them, women were seen as less promotable to men. According to Robbins (2001) the attribution theory states that when individuals observe behavior, they attempt to determine whether it is internally or externally caused. Internally caused behaviors are those that are believed to be under the control of the individual. Externally caused behavior is seen as resulting from outside causes. The argument here is that because women are not visible to supervisors even their 
performance is not likely to be attributed to them and therefore they are likely not to be recommended for promotion. This issue may be critical where employees' recommendation for promotion depends on the supervisor. To be able to wield power and influence a woman must be known to be an individual who deserves to be there because of personal or professional power.

Several authors (Adler and Izraeli, 1992; Morrison, White and Velsor, 1992; Driscoll and Goldberg, 1993; Vinnicombe and Bank, 2003) state that visibility is increased by being involved in challenging assignments, participation in social events, and Professional events, and networks.

\section{Challenging Assignments}

Challenging assignments involve adding an employee's responsibility and this gives the employee a sense of recognition as they stand out (Aswathappa, 2005). Armstrong and Murlins (2004) state that recognition is necessary in career advancement. Recognition could be achieved by accepting challenging assignments which stretch and compliment one's knowledge and then learn as much as one could. Dessler (2008) notes that challenging assignments provide employees with opportunities for achievement and also motivation.

Lee (2002) found that ability to take challenging assignments helped computer professionals to fulfill growth needs. Cox and Cooper (1988) found that women who had succeeded in their careers had been given challenge early in their career and that gave them opportunity to prove their abilities. Also, studies done by Metcalfe (1989) showed that women who had advanced in their careers rated challenging assignments as important for career advancement.

Dessler (2008) views challenging assignments as developmental opportunities. He states that women had great difficulty in getting geographic mobility opportunities and they needed to be proactive to get such assignments.

Undertaking challenging assignments entails ability and willingness to assume a heavy workload and putting in long face hours (Dessler, 2008), because this demonstrates commitment to the organization and career (Snape et al., 1994) due to the increased responsibilities. Research done by Vinnicombe and Colwill, (1997 indicated that successful women attributed their career success to hard work which led to good performance. Pine (2002) in Zhong (2006) recommends that women must stand out through hard work and being good at what they do.

In contribution to heavy work load, Lee (2002) posits that apart from assuming long and flexible working hours by extending the work environment to working outside of normal hours heavy work load also entails having a preoccupation with work related issues like undertaking geographical assignments. This could be an indication of commitment to the job and organization. Chew and Zhu (2002) indicate that in organizations, it is generally expected that international assignments lead to career advancement an employees aspiring to be managers ought to consider this issue. This is especially the case for young employees because today's expatriates are not likely to be in the golden years of career 
taking on one last challenge and be rewarded with very attractive compensation. Most expatriates of today take overseas stints to upgrade themselves to enhance their career prospects. Powell and Graves (2003) say that service in different geographic locations presents employees with opportunities to polish their skills by working on high visibility projects. The two authors add that these opportunities are in most cases allocated to men because of the assumption that women will be reluctant to take them because of family commitments but in actual sense this is not the case as women do not show reluctance to attend to geographical assignments. Because of the limited access to geographical assignments, women's career advancement is hindered (Powell and Graves, 2003).

\section{Participation in Social and Professional events}

To increase visibility women need to participate in social events. This includes being seen at social functions, being effective in professional associations and developing powerful allies who speak well of you (Robbins and Coulter, 1999).

Attending social gatherings increases ones visibility (Robbins and DeCenzo, 2007). According to (Aswathappa, 2005) one's presence at social functions and events provide social interaction and a source of information about career opportunities. To enhance career advancement opportunity one needs to join a support group to be able to listen to others and develop empathy and other key interpersonal relationships (Zajas, 1995).

Vinnicombe and Colwill, (1997) indicate that associations can make women more visible in society encourage them to contribute and develop. The two authors add that women's associations may provide a network for women to offer specific support for their efforts in the work place and bring together women who have similar professional qualifications to share information about their occupations and career guidance. According to Walsh and Borkowski (2006) professional networks provide instrumental benefits to their members such as information exchange, access to resources and promotional opportunities. In addition, Dessler (2008) observes that a study on minority working women in the United States showed that 40 percent of the women attributed their lack of career advancement to lack of networking with influential colleagues. Hansen (2006) asserts that is important for one to focus on people with power and influence in the organization to benefit from their clout. She observes that women tended to focus on people at lower than themselves.

\section{Networking}

According to Murphy in Davidson and Cooper (1993) a network is a group which encourages women to help each other in their respective jobs and is a source of information and advice for them. Kandola (2004) points out that the purpose served by networks was that of fulfilling the need to be seen to be doing something and adds that informal networks might hinder or improve an employees chances of promotion All the same, several authors have stated that networks are important for increasing visibility and career advancement (Robbins and Coulter, 1999; Vinnicombe and Singh, 2003; Aycan, 2004; Maxfield, 2005; Ogden et al., 2006). According to Ogden et al., (2006) networking was an important enabler to career development . Robbins and Coulter (1999) state that networks lead to career success. According to Ackah and Heaton (2003) men used networks to obtain promotions. Aycan (2004) states that women who had made it to top 
management in Turkey had access to networks. Networking is related to the social learning theory. The social learning theory posits the people learn from observing others. The theory contributes to adult learning by highlighting the importance of social context and explicating the process of modeling and mentoring (Arokiasamy, 2007). To this end, one may argue that networks provide women with the context where they can learn by observing role models and being mentored.

Zhong (2006) states that women need to set up their networks and participate in men's networks. Maxifield (2005) contents that women found networking challenging and thus they lacked the important tool of networking. Ackah and Heaton (2003) state that women were excluded from the networks through which they could make themselves known and learn about promotion processes. Studies conducted in Tanzania showed that women who do not network remain vulnerable and liable to being rendered invisible and never remembered when promotions were being discussed (Adler and Izraeli, 1994).

Two types of networking include internal and external networking. Internal networking refers to networking within an organization. According to Maxifield (2005) internal networking is deemed to be a characteristic or behaviour thought to be important to progress in an organization; if you struggle to network internally, you may be seen as unable to represent the organization effectively on an external basis. External networking is the ability to network with others outside the organization. The ability to network was perceived as a business skill that is important for building relations with clients, and as a method by which one's visibility to senior management demonstrated, and this way enhanced career progression (Maxfield 2005). According to Ackah and Heaton (2003) a network of friends, colleagues, and clients can be valuable means to career advancement because it can prove beneficial in getting things done.

Building a network of mutual friends who can be called upon to assist in career matters can help an employee to find the best career opportunities and get in a better financial situation. For many employees, their work group is a source of social interaction where they can also share their frustrations and feelings of satisfaction. Aswathappa, (2005) states that an employee who communicates with fellow employees may provide get information about career choices. Peer network is one interpersonal determinant which involves supportive relationship at work and as such supports advancement (Nikandrou and Panyotopoulou and Apospori, 2006)

Networking with clients enables an employee to learn about the clients views about the products or services offered by the organization. Such involvement can lead to the employee's success at the work place. Employees who network with clients look good to management because they help to strengthen the employer's stability (Spiegel, 2008). The author adds that such employees may receive increased earnings.

The objective of this study was to assess whether women are visible in their organizations in Kenya.

\section{Data and Methods}


The study involved Federation of Kenya (FKE) member organizations. FKE has 34 member organizations which fall in 14 sectors. The population of study was the women employees whose population was 7,353. To cater for all the 14 sectors stratified sampling was applied. After that a sample size of 400 respondents was drawn using simple random sampling. Data was analyzed using means and standard deviations.

In this study a questionnaire was used to collect quantitative and qualitative data. Respondents had to give their opinions in relation to career advancement and visibility. Visibility was measured using five items ranging from hard work to having a network of influential colleagues. The measures used likert type of questions with responses ranging from 1 as strongly disagree to 5 as strongly agree.

\section{The Results}

As indicated in the table below the ability to undertake assignments which involve geographic assignments had the highest mean at 3.01 whereas the lowest was network of customers at 2.04. The results indicate that women do not network much with their customers have little involvement in professional networks. The results further show that the women moderately agreed to have networks of influential friends and colleagues. Women were only trying to increase visibility through their ability to undertake assignments of geographic mobility, participating in social events, working long hours and undertaking heavy workloads.

Descriptive Statistics of Visibility

\begin{tabular}{|c|c|c|c|c|c|}
\hline Construct & $\mathrm{N}$ & Minimum & Maximum & Mean & $\begin{array}{l}\text { Std. } \\
\text { Deviation }\end{array}$ \\
\hline $\begin{array}{l}\text { I am able to undertake a heavy } \\
\text { workload }\end{array}$ & 366 & 1 & 5 & 2.80 & 1.417 \\
\hline $\begin{array}{l}\text { I am always willing to work for } \\
\text { long hours }\end{array}$ & 366 & 1 & 5 & 2.83 & 1.418 \\
\hline $\begin{array}{l}\text { I am able to undertake } \\
\text { assignments which involve } \\
\text { geographical mobility }\end{array}$ & 366 & 1 & 5 & 3.01 & 1.304 \\
\hline $\begin{array}{l}\text { I like participating in social } \\
\text { events }\end{array}$ & 366 & 1 & 5 & 2.87 & 1.399 \\
\hline $\begin{array}{l}\text { I am involved in professional } \\
\text { associations }\end{array}$ & 366 & 1 & 5 & 2.09 & 1.352 \\
\hline $\begin{array}{l}\text { I have a network of influential } \\
\text { friends }\end{array}$ & 366 & 1 & 5 & 2.49 & 1.374 \\
\hline $\begin{array}{l}\text { I have a network of influential } \\
\text { colleagues }\end{array}$ & 366 & 1 & 5 & 2.28 & 1.374 \\
\hline $\begin{array}{l}\text { I have a strong network of } \\
\text { customers }\end{array}$ & 366 & 1 & 5 & 2.04 & 1.358 \\
\hline Valid N (listwise) & 366 & & & & \\
\hline
\end{tabular}




\section{Discussion and Recommendations}

The results showed that women were visible with regard to ability to undertake assignments which involve geographic assignments. The women also agreed to assuming heavy workload and were willing to put in more work hours. The women there tended to indicate some agreement of commitment in line with what Dessler (2008) argued. The women tended to agree that they participated in social events and so they were gaining benefits of social interaction. However the low networking with customers might mean that they were failing to impress the management in their organizations and therefore losing on incentives. Spiegel (2008) argues that a network with clients makes employees look good to management and as such they may receive increased earnings. Also the low involvement in professional associations might result into being invisible and missing out on information exchange which are important for career advancement.

On the basis of these conclusions, this study therefore recommends that women should try to enhance their visibility by joining professional associations, networking with clients and influential colleagues and friends because these were their weak areas. By so doing they could reap the benefits of increased visibility mainly career advancement.

\section{References}

Ackah, C. and Heaton, N ( 2003). Human Resource Management Careers: Different paths for men and Women? Career Development International. 6/3 134-142

Adler, N.J. and Izraeli D.N. ( 1994). Competitive Frontiers: Women Managers in a Global Economy. Blackwell Publishers.

Alimo-Metcalfe, B. ( 1997). Leadership and Assessment : Women in Management ( Ed. Buckley, A.) Prentice Hall of India.

Apospori,E. Nikandrou, I. and Panayotopoulou, L. and (2008). "The Impact of Individual and Organizational Characteristics on Work-family Conflict and Career Outcome". Journal of Managerial PsychologyVol. 23 No. 5, pp. 576-598

Aswathappa, K. ( 2005). Human Resource and Personnel Management. McGraw Hill Publishing Company, New Delhi

Burke, R.J., Burgess, Z and Barry, F. (2006). Organizational Practices Supporting Women and their Satisfaction and Well-being. Women in Management Review. Vol.21, No.5. 
Chew, I.K,H and Zhu, W. ( 2002) Factors influencing Singapore managers' career aspiration in International Assignments. Career Development International. Vol 7, Issue 2 pp 96-108

Cox, C. and Cooper, C.L. ( 1998). High Flyers. Oxford, Basil Blackwell

Davidson J. and Cooper L. ( 1993). An Overview. Working Women in the European Community.

Dessler G. (2008). Human Resource Management. Pearson Education, Inc., Upper Saddle River, New Jersey.

Driscoll, D.M. and Goldberg, C.R. ( 1993). Members of the Club. Maxwell MacMillan , Canada.

Ismail, M. and Arokiasamy, L. ( 2007 ). Exploring Mentoring as a tool for Career Advancement of Academics in Private Higher education Institutions in Malaysia. The Journal of International Social Research. Vol.1/1 Fall

Garavan, T.N., O’Brien F. and O’Hanlon, D.( 2006). Career advancement of hotel managers since graduation: a comparative study. Journal of Personnel Review, Vol.35, No.3pp.252-280

Hansen, K. ( 2008 ). 10 Powerful Career Strategies for Women. Quintessential Careers.

Lee, P. (2002). "Career Goals and Career Management Strategy among Information Technology Professionals." Career development International 7/1 pp6-13.

Lemons, M. A., \& Parzinger, M. J. (2001). Designing women: A qualitative study of the glass ceiling for women in technology. S.A.M. Advanced Management Journal, 66 (2), 411

Kandola, B. ( 2004). Skills Development. The Missing Link in Increasing Diversity in Leadership Industrial and Commercial Training. Vol.36 No.4 pp 143-147

Kirchmeyer, C. (1998), "Determinants of managerial career success: evidence and explanation of male/female differences", Journal of Management, Vol. 24 No.6, pp.67393.

Hansen, K. ( 2008 ). 10 Powerful Career Strategies for Women. Quintessential Careers

Maxifield, S.(2005). Modifying Best Practices in Women's Career Advancement for the Latin American Context. Women in Management Review. Vol.2,No.4 pp 249-261

Morrison, A.M., White, R.P. and Velsor, E.V. (1992). Breaking the Glass Ceiling. ( Personnel Decisions. USA. 
Networking, www.savvy employement.com

Ogden, S.M., McTarish and Mckean( 2006). Clearing the way for Gender Balance in the Management of UK financial Services Industry. Enablers and Barriers. Women in Management Review, Vol. 21 No.1 pp 40-53.

Powell, G.N. and Graves, L.M. (2003). Women and men in management, 3 rd ed. Thousand Oaks,. CA: Sage. Powell, G.N. (Ed.)

Robbins, S.P. and DeCenzo, D.A. (2007). Supervision Today ( $5^{\text {th }}$ Edition). Pearson, Prentice Hall.

SNape T., Redman and Bamber Eds.( 1994). Strategies and Tecniques for Human Resource Management. Blackwell Publishers, the Publishing Imprint of Basil. Blackwell LTD. Oxford UK

Spiegel, E.(2008). It's Time to Start Networking.Internet.comsite

Vinnicombe ,S. and Bank, J. ( 2003) . Women with Attitude. Routledge, London

Vinnicombe, S. and Colwill, N.L. ( 1997). Women in Management. Asoke K. Ghosh, Prentice- Hall of India Private LTD. New Delhi -110001

Vinnicombe ,S. and Singh ,V. and ( 2003). Lockes and Keys to the Boardroom. Women in Management Review.Vol 18 No6 pp 325-333

Walsh, A.M. and Borkowski, S.C. ( 2006). Professional associations in the health industry: Factors affecting female executive participation. Journal of Women in Management Review. Vol.21, Issue 5 pp365-375

Zajas, J.J. ( 1995). Assesing your executive and personal success. Executive Development, Vol. 8 No.3, 1995, pp.18 -22

Zhong, Y.M.S. (2006). Factors Affecting Women's Career Advancement in the Hospitality Industry. Perceptions of Students, Educators, and Industry Recriuters. PhD Dissertation. 
The Journal of Language, Technology \& Entrepreneurship in Africa, Vol. 2. No.1. 2010, ISSN 1998-1279 